\title{
Detection of infections of the eye with Chlamydia trachomatis by the polymerase chain reaction
}

\author{
Jun Fan, ${ }^{*}$ Wen H. Zhang, Yu Y. Wu, Xiou Y. Jing \& Eric C.J. Claas ${ }^{1}$ \\ Beijing Institute of Ophthalmology, 17 Hou Gou Lane, Chongwenmen, Beijing, 100005, China; \\ ${ }^{1}$ Erasmus University, Department of Virology, P.O. Box 1738, 3000 DR Rotterdam, The Netherlands \\ (* requests for offprints)
}

Accepted 16 December, 1993

Key words: Chlamydia trachomatis, diagnosis, conjunctivitis, immunofluorescence, PCR

\begin{abstract}
The aim of this study was to test the diagnostic feasibility of the polymerase chain reaction (PCR) for detection of infections with Chlamydia trachomatis in eye swabs from patients with conjunctivitis, and to establish the basic technique of the PCR for epidemiological survey. The results of the PCR were compared with the Mikro Trak immunofluorescence assay (IFA). From 49 specimens of patients with conjunctivitis, 31 were found positive by PCR (63\%) and 23 by IFA (47\%). On the other hand, in 10 normal eye specimens and 10 non-Chlamydia trachoma conjunctivitis specimens no Chlamydia trachomatis was detected.
\end{abstract}

\section{Introduction}

Chlamydia trachomatis is an obligate intracellular bacterium that infects mucosal epithelial cells of humans, causing blinding trachoma and sexually transmitted urogenital diseases. Trachoma is one of the leading causes of blindness in the world [1-3].

In China infections with Chlamydia trachomatis have been a major cause of ocular disorders and were the largest cause of blindness during the 1950s. Today Chlamydia trachomatis eye infections still are a major problem in China. The trachoma prevalence rate is about $7.74 \%$ to over $30 \%$ [4,5]. Especially, Chlamydia trachomatis serotype $\mathrm{Ba}$ and $\mathrm{C}$ are the most important etiological agents in ocular diseases in Northern China [6].

Cell culture is regarded the standard method of detection of Chlamydia. However, besides that it is time-consuming and expensive, culturing of ocular specimens for Chlamydia is often inferior to noncultural methods. Although culture is the more sensitive technique for urogenital specimens [7,8], direct fluorescence assays, enzyme immunoassays and DNA hybridization techniques achieve a higher sensitivity in diagnosing infections of C. trachomatis of the eye [9-11].

Recently the polymerase chain reaction (PCR), an enzymatic amplification in vitro of a nucleic acid target, was used to detect $\mathrm{C}$. trachomatis. The sensitivity of this technique in urogenital specimens was shown to be superior to cell culture [12-14]. In a previous study the sensitivity and specificity of PCR primers selected from sequences of the $16 \mathrm{~S}$ rRNA gene and the endogenous plasmid of C. trachomatis was described [13]. Subsequently these primer sets were used for followup diagnosis of C. trachomatis infections in urogenital specimens [15]. In the present study, we have applied this PCR technique for detection of C. trachomatis in eye swabs and compared the results to the Mikro Trak immunofluorescence assay.

\section{Materials and methods}

\section{Clinical specimens}

A total of 59 upper and lower tarsal conjunctival swabs were collected at the Beijing Institute of Ophthalmol- 
ogy. This group consisted of 49 clinically suspected Chlamydia trachomatis conjunctival swabs and ten other conjunctivitis cases. No laboratory diagnosis could be carried out to determine the etiology of the disease in the last group. Based on the clinical signs this group consisted of: two acute follicular conjunctival swabs probably with an adenoviral etiology; two acute haemorrhagic conjunctival swabs, two epidemic keratoconjunctivitis swabs and two pharyngoconjunctivitis fever swabs with an unknown viral etiology; and two chronic conjunctivitis swabs which were probably bacterial infections. In addition, as a control group 10 normal eye swabs of children were collected. The swabs were suspended in $1 \mathrm{ml}$ viral transport medium: $50 \% \mathrm{~L} 15$ Medium, $7.46 \%$ Carbohydrate, $0.18 \%$ potassium salt, $0.07 \%$ amino acids, and $1 \%$ albumin (Novo Biolabs $\mathrm{Ltd}$, Cambridge, UK). For DNA extraction $0.4 \mathrm{ml}$ of this sample solution was used.

\section{DNA extraction}

Sodium dodecyl sulfate (SDS) was added to $0.4 \mathrm{ml}$ of the sample solution at a final concentration of $0.5 \%$. The sample was treated with proteinase $\mathrm{K}(20 \mu \mathrm{g} / \mathrm{ml})$ for $30 \mathrm{~min}$ at $37^{\circ} \mathrm{C}$. The DNA was isolated by extraction with phenol, phenol-chloroform-isoamylalcohol (25:24:1) and chloroform-isoamylalcohol (24:1) respectively, and collected by ethanol precipitation [16]. The DNA was resuspended in $50 \mu 1$ of TE buffer (10 mM Tris-HCl, pH 7.4; 1 mM EDTA pH 8.0). For PCR analysis, 5-10 $\mu$ l of this solution (50-100 ng of DNA) was used.

\section{Amplification and detection of Chlamydial DNA}

Two sets of oligonucleotide primers were used. The first set (primer R1 = GTGGA TAGTC TCAAC CCTAT; primer R2 = TATCT GTCCT TGCGG AAAAC; probe = ACTCA AAAGA ATTGA CGGGG GCCCG CACAA) was derived from 16S rRNA gene sequences of Chlamydia psittaci [17] and generated amplified products of $208 \mathrm{bp}$ with all three Chlamydia species, i.e., C. trachomatis, C. psittaci, and C. pneumoniae. The second primer set (T1 = GGACA AATCG TATCT CGG, T2 = GAAAC CAACT CTACG CTG, probe = CGCAG CGCTA GAGGC CGGTC TATTT ATGAT) was derived from sequences of the common endogenous plasmid of C. trachomatis [18] and generated specific 517 bp amplified products with all known C. trachomatis serovars. The DNA isolated from the specimens from children without ocular disorders were used as negative control and DNA isolated from the Chlamydia trachoma strain TE55 was used as positive control in the PCR experiments.

The amplification reaction was essentially performed as described by Saiki [19]. A volume of $100 \mu 1$ reaction solution containing 50-100 ng of sample DNA, $10 \mathrm{mM}$ Tris $\mathrm{HCl}(\mathrm{pH} 8.0) ; 50 \mathrm{mM} \mathrm{KCl} ; 2.5 \mathrm{mM}$ $\mathrm{MgCl}_{2} ; 0.01 \%$ gelatin; $200 \mu \mathrm{M}$ of dATP, dCTP, dGTP, and dTTP; 50 pmol of each primer; and $1 \mathrm{U}$ of Taq DNA polymerase (SINO - AMERICAN Biotechnology company, China). Finally, $60 \mu 1$ of mineral oil was added to prevent evaporation. The amplification was performed in a PCR processor (SINO - AMERICAN Biotechnology company, China) and each cycle consisted of a denaturation step at $94^{\circ} \mathrm{C}$ for $40 \mathrm{sec}$, a primer annealing step at $42^{\circ} \mathrm{C}$ for $60 \mathrm{sec}$, and an elongation step at $74^{\circ} \mathrm{C}$ for $90 \mathrm{sec}$. After 40 cycles, $10 \mu \mathrm{l}$ of the reaction mixture was analysed by electrophoresis on a $1.5 \%$ agarose gel [15].

For dot spot analysis, $20 \mu 1$ of the reaction mixture was spotted on nitrocellulose filter. After the fluid had dried, the reaction products were denatured in $0.5 \mathrm{~N}$ $\mathrm{NaOH} ; 1.5 \mathrm{M} \mathrm{NaCl}$ for $10 \mathrm{~min}$, and twice neutralized in $0.5 \mathrm{M}$ Tris $\mathrm{HCl} \mathrm{pH} \mathrm{7.0;3} \mathrm{M} \mathrm{NaCl}$ for $15 \mathrm{~min}$. The filter was baked for $2 \mathrm{~h}$ under vacuum at $80^{\circ} \mathrm{C}$. The oligonucleotide probes were labelled by transfer of the gamma- ${ }^{32} P$ from $\left[\right.$ gamma- ${ }^{32} P$ ]ATP using T4 polynucleotide kinase [16]. Prehybridization was performed at $65^{\circ} \mathrm{C}$ for $2 \mathrm{~h}$ in a solution containing $6 \times \mathrm{SSC}, 5 \times$ Denhardts solution, $0.2 \% \mathrm{SDS}$, and $100 \mu \mathrm{g} / \mathrm{ml}$ denatured, fragmented salmon sperm DNA. Hybridization was carried out at $37^{\circ} \mathrm{C}$ overnight in a solution containing $6 \times \mathrm{SSC}, 10 \times$ Denhardts solution, and the probe. Then the filter was washed in $2 \times$ SSC; $0.5 \%$ SDS at respectively $37^{\circ} \mathrm{C}, 42^{\circ} \mathrm{C}$, and $55^{\circ} \mathrm{C}$ for $15 \mathrm{~min}$. Autoradiography was performed overnight on a $\mathrm{X}$ ray film at $-80^{\circ} \mathrm{C}$.

Detection of Chlamydia antigen by the Micro Trak IFA (Syva, USA) diagnostic kit was performed according to the protocols enclosed in the kit.

\section{Results}

The results of Chlamydia trachomatis detection by PCR and IFA on the clinical specimens are summarized in Table 1. From the 49 specimens of clinical suspected $\mathrm{C}$. trachomatis conjunctivitis, 31 were found to be positive in PCR with the rRNA primers and with the plasmid primers. In the other 10 non-C. trachomatis 
Table 1. Chlamydia trachomatis detection by PCR and IFA.

\begin{tabular}{lrr}
\hline & PCR & \multicolumn{1}{c}{ IFA } \\
\hline Trachoma & $31 / 49$ & $23 / 49$ \\
Other conjunctivitis & $0 / 10$ & $0 / 10$ \\
Control group & $0 / 10$ & $0 / 10$ \\
\hline
\end{tabular}

Table 2. Comparison between the results of PCR and IFA for detection of Chlamydia trachomatis in trachoma specimens.

\begin{tabular}{lrrrr} 
& \multicolumn{1}{c}{ IFA } & & & \\
\cline { 2 - 4 } & + & $\mathrm{nj}^{*}$ & - & \\
\hline PCR + & 22 & 3 & 6 & 31 \\
PCR - & 1 & & 17 & 18 \\
\cline { 2 - 4 } & & & & \\
& 23 & 3 & 23 & 49 \\
\hline
\end{tabular}

$n j^{*}$ These samples could not

be judged in the IFA.

conjunctivitis specimens and the 10 normal eye specimens no Chlamydial DNA could be detected.

Some of the PCR results after amplification of the Chlamydial DNA on agarose gel and after dot spot hybridisation are shown in Figs 1 and 2 respectively. A comparison between the PCR and IFA results is presented in Table 2.

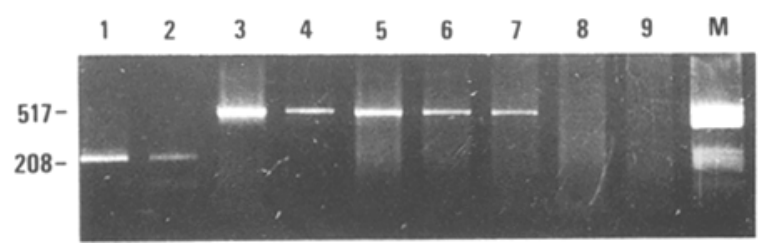

Fig. 1. Detection of amplification products by electrophoresis on a $1.5 \%$ agarose gel. Lane 1 shows the 208 bp product of TE 55 (rRNA primers), lane 2 of a positive specimen (rRNA primers), lane 3 the 517 bp PCR product of the TE55 strain (plasmid primers), and lane 4-7 the products generated with DNA from 5 of the specimens (plasmid primers). Lane 8-9 are the negative controls, and $\mathrm{M}$ is the marker (pBR322 digested with HaeIII).

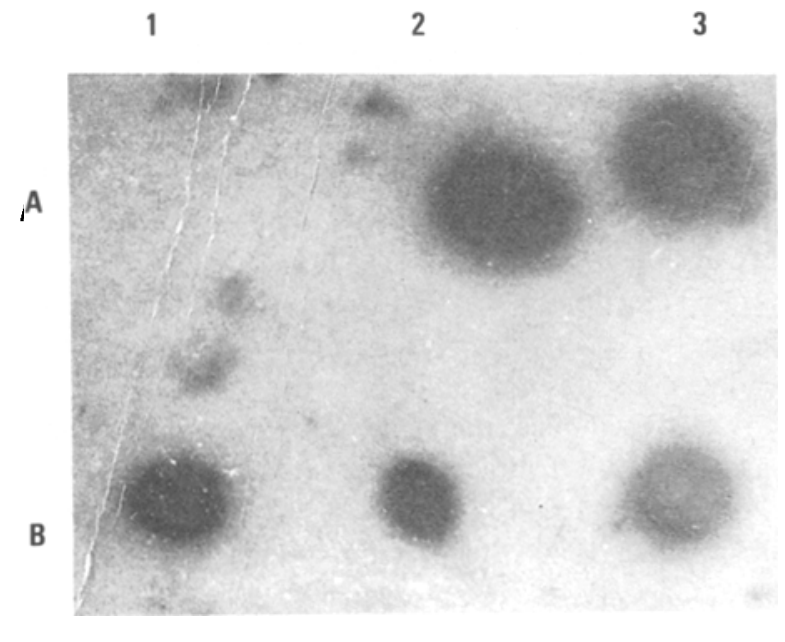

Fig. 2. Hybridisation results after manual dot spot analysis of the PCR products. Positive hybridisation signals can be seen on spots B1, B2, B3. These samples are positive for Chlamydia trachomatis. $\mathrm{A} 1$ is the negative control, $\mathrm{A} 2$ and $\mathrm{A} 3$ positive controls of TE 55.

\section{Discussion}

Using the PCR, one copy of DNA can be amplified in vitro up to millions of copies within hours. This makes this technique theoretically the most sensitive diagnostic method available at the moment. The specificity is very high as well, and therefore the PCR could have great advantages in clinical diagnosis. Recently, the PCR was shown to be very effective in diagnosing urogenital C. trachomatis infections [9-11].

In the present study we used two sets of primers to amplify two different targets of C. trachomatis DNA in specimens from patients with conjunctivitis of the eye. The first primer set generated a $208 \mathrm{bp}$ amplified product with on the DNA coding for the rRNA genes from C. trachomatis, C. psittaci, and C. pneumoniae. The second set of primers annealed to sequences from the endogenous plasmid of $\mathrm{C}$. trachomatis and generated a 517 bp amplified product with all known C. trachomatis serotypes. Previously, the sensitivity and specificity of these two primer sets was shown $[10,15]$.

We used the two sets of primers to subject 69 eye specimens to PCR analysis. Among the 49 trachoma specimens, 31 specimens were positive for $C$. trachomatis. The same samples also were tested in an IFA, and 23 were found positive. From the IFA positive samples, 22 were confirmed by PCR. One was not detected by either primer set. Unfortunately no culturing or other assay could be carried out. Six IFA 
negative and 3 specimens which could not be judged by IFA were detected positive by PCR. This demonstrated that PCR is more sensitive than the IFA. In the non-C. trachomatis conjunctivitis specimens and normal eye specimens no positive signals were detected by PCR or IFA. The PCR positive, IFA negative samples can be considered true positive, as the PCR was carried out on two essentially different targets of the Chlamydial genome, i.e. the chromosomal rRNA genes and the endogenous plasmid.

Not all samples contain the micro-organism, which is known from the trachoma pathology. In later stages, the etiological agent is not detected any longer, conjunctival scarring often occurs without detectable $\mathrm{C}$. trachomatis $[20,21]$.

It can be concluded that the sensitivity of both primer sets for diagnosing trachoma caused by C. trachomatis was superior to the IFA. The specificity of the method was also known. Thus, besides its application to urogenital specimens, the PCR can also be used as a rapid and sensitive method for diagnosing infections of the eye with $\mathrm{C}$. trachomatis.

One of the major disadvantages of culturing $\mathrm{C}$. trachomatis, is the sensitivity of the micro-organism. Extreme care has to be taken in collecting and storing the clinical samples, because the viability of the Chlamydiae easily decreases. When using PCR it is not necessary to have viable Chlamydiae in the specimens, which makes it easier to handle. Of course, the same counts for IFA, but as shown the sensitivity of PCR is superior, and therefore could become a very useful tool in the diagnosis of $\mathrm{C}$. trachomatis.

Most positive results could simply be detected by the presence of the specific DNA band on the agarose gel. The hybridisation offers an extra confirmation of the results and therefore increases the specificity.

PCR can be considered rapid, if compared to cell culture. However, many antigen detection and nucleic acid hybridisation assays are faster, but are less sensitive $[7,8]$. We are now trying to directly amplify the sample solution after incubation with proteinase $K$, which would save lots of time. Then the whole procedure would be finished within half a day.

\section{References}

1. Grayston JT, Wang SP. New knowledge of Chlamydia and the diseases they cause. J Infect Dis 1975; 132: 87-105.
2. Prevention of blindness. Prevalence and severity of trachoma. Wkly Epidemiol Rec 1992; 67: 41-3.

3. Darougar S, Monnickendam MA, Woodland RM. Management and prevention of ocular viral and chlamydial infections. Crit Rev Microbiol 1989; 16: 369-418.

4. Hu C. An epidemiology survey of trachoma in Shunyi county, Beijing. Chin J Ophthalmol 1989;25: 175-8.

5. Wei JX. Feasibility of the new WHO trachoma grading system in China. Chin J Ophthalmol 1992; 28: 270-2.

6. Zhang L. Chlamydia trachomatis immunotypes in trachoma epidemic areas of North China. Chin J Ophthalmol 1991; 27: 67-70.

7. Hall CJ, Nelder C. Comparison of three non-culture techniques for detection of Chlamydia trachomatis in genital tract specimens. Eur J Clin Microbiol Infect Dis 1989; 8: 866-70.

8. Peterson EM, Oda R, Alexander R, de la Maza LM. Molecular techniques for the detection of Chlamydia trachomatis. J Clin Microbiol 1989; 27: 2359-63.

9. Schachter J, Moncada J, Dawson CR, Sheppard J, Courtright P, Said $\mathrm{M}$ et al. Nonculture methods for diagnosing chlamydial infection in patients with trachoma; a clue to the pathogenesis of the disease. J Infect Dis 1988; 158: 1347-52.

10. Taylor HR, Rapoza PA, West S, Johnson S, Munoz B, Katala $S$ et al. The epidemiology of infection in trachoma. Invest Ophthalmol Vis Sci 1989; 30: 1823-33.

11. Dean D, Palmer L, Pant CR, Courtright P, Falkow S, O'Hanley $P$. Use of a Chlamydia trachomatis DNA probe for detection of ocular chlamydiae. J Clin Microbiol 1989; 27: 1062-7.

12. Dulith B, Bebear C, Rodriguez P, Vekris A, Bonnet J, Garret $M$. Specific amplification of a DNA sequence common to all Chlamydia trachomatis serovars using the polymerase chain reaction. Res Microbiol 1989; 140: 7-16.

13. Claas HC, Melchers WJ, de Bruijn IH, de Graaf M, van Dijk WC, Lindeman J, Quint WG. Detection of Chlamydia trachomatis in clinical specimens by the polymerase chain reaction. Eur J Clin Microbiol Infect Dis 1990; 9: 864-8.

14. Lucotle G, Petit MC, Francois MH. Detection of Chlamydia trachomatis by use of polymerase chain reaction. Molec Cell Probes 1992; 6: 89-92.

15. Claas HCJ, Wagenvoort JHT, Niesters HGM, van Rijsoort-Vos JH, Tio TT, Quint WGV. Diagnostic value of the polymerase chain reaction for Chlamydia detection as determined in a follow-up study. J Clin Microbiol 1991; 29: 42-5.

16. Sambrook J, Fritsch EF, Maniatis T. Molecular cloning; a laboratory manual, 2nd edition, Cold Spring Harbor laboratory press, 1989

17. Weisburg WG, Hatch TP, Woese CR. Eubacterial origin of Chlamydiae. J Bacteriol 1986; 167: 570-4.

18. Sriprakash KS, Macavoy ES. Characterization and sequence of a plasmid from the trachoma biovar of Chlamydia trachomatis. Plasmid 1987; 18: 205-14.

19. Saiki RK, Scharf S, Faloona F, Mullis KB, Horn GT, Erlich $\mathrm{HA}$ et al. Enzymatic amplification of beta-globin genomic sequences and restriction site analysis for diagnosis of sickle cell anemia. Science 1985; 230: 1350-4.

20. Dawson CR, Jones BR, Tarizzo ML. Guide to trachoma control in programmes for the prevention of blindness. Geneva, World Health Organization, 1981.

21. Elbagir A, Mardh PA. Evaluation of Chlamydia tests in early trachoma. APMIS 1990; 98: 276-80. 